\title{
The correlation between the estimated non-invasive liver fibrosis and various clinical, biological and imaging parameters in chronic viral hepatopathy
}

\author{
Corelaţia dintre gradul de fibroză hepatica estimat non-invaziv şi \\ diverşi parametri clinici, biologici şi imagistici în hepatopatiile cronice virale
}

\author{
Cristina Olariu', Adriana Nurciu², Iulia Vasilescu², Cătălin Preda², Mihai Olariu² \\ ${ }^{1}$ Universitatea de Medicină şi Farmacie „Carol Davila“, Bucureşti, România \\ ${ }^{2}$ Institutul Naţional de Boli Infecţioase "Prof. Dr. Matei Balş", Bucureşti, România
}

\begin{abstract}
REZUMAT
Obiective. Evaluarea corelaţiilor dintre o serie de parametri clinici, biologici şi endoscopici şi gradul de fibroză hepatică, aşa cum reiese la Fibromax/Fibroscan, în scopul stabilirii unor repere utile clinicienilor.

Material şi metodă. Studiul retrospectiv, randomizat, a fost făcut pe un lot de 132 pacienţi cu hepatopatii virale în diferite stadii de evoluţie - de la hepatite cronice cu modificări clinice şi biologice minore la ciroze hepatice avansate. Gradul de fibroză a fost evaluat cu ajutorul testelor non-invazive (Fibromax/Fibroscan), utilizându-se pentru uniformizare si standardizare scorul METAVIR, iar în ceea ce priveşte criteriile endoscopice de hipertensiune portală, pacienţii au fost clasificaţi în 5 categorii: fără varice; varice mici/ medii/ mari; gastropatie portalhipertensivă.

Rezultate. Etiologia virală predominantă în cadrul lotului a fost VHC $(75,76 \%)$, iar pacienţii cu infecţie concomitentă VHB+VHD au prezentat grad maxim de fibroză (F4) la determinările non-invazive. Proporţia cazurilor cu fibroză avansată (F4) s-a observat la categoria de vârstă 41-62 ani cu o distribuţie egală, indiferent de sexul pacienţilor. Pacienţii cu trombocitopenie severă $(97,43 \%)$ au avut grad maxim de fibroză (F4) la determinările non-invazive, iar aproape $97 \%$ dintre pacienţii cu modificări endoscopice au avut rezultate F3 sau F4 la Fibromax/Fibroscan.

Discuţii. Limitele acestui studiu au fost reprezentate de imposibilitatea urmăririi în dinamică a corelaţiei dintre gradul de fibroză hepatică estimat la Fibromax/Fibroscan şi parametrii luaţi în calcul (fiind un studiu retrospectiv), lipsa unui lot martor, dimensiunile relativ reduse ale lotului şi repartiţia neuniformă a cazurilor, cu dominanţa clară a fibrozelor avansate.

Concluzii. Anumiţi parametri biologici, endoscopici şi imagistici se corelează semnificativ cu rezultatul estimărilor non-invazive ale gradului de fibroză. Dintre aceştia, trombocitopenia este un marker semnificativ statistic, iar criteriile endoscopice sugestive pentru hipertensiune portală sugerează un grad avansat de fibroză hepatică. Utilizarea combinată a acestor factori în cadrul unor sisteme-scor ar putea creşte acurateţea estimării gradului de fibroză, apreciată în prezent doar prin teste specifice.
\end{abstract}

Cuvinte cheie: hepatită cronică virală, fibroză hepatică, Fibroscan, Fibromax, endoscopie digestivă superioară, trombocitopenie

\begin{abstract}
Objectives. Evaluating the correlations between a series of clinical, biological and endoscopic parameters and the degree of hepatic fibrosis as it turns out on Fibroma/Fibro scan, with the purpose of establishing useful criteria for clinicians.

Material and methods. It was used a retrospective randomized study on 132 patients with viral hepatitis in various stages of evolution, from chronic hepatitis with minor clinical and biological changes to advanced hepatic cirrhosis. The fibrosis degree was evaluated with non-invasive tests (Fibroma/Fibro scan), using for uniformisation and standardization the METAVIR score, and regarding the endoscopic criteria of portal hypertension, the patients were classified in 5 categories - without varices; small, medium or large varices; portal hypertensive gastropathy.
\end{abstract}




\begin{abstract}
Results. The predominant viral etiology within the lot was VHC $(75,76 \%)$ and the patients with concomitant infection $\mathrm{VHB}+\mathrm{VHD}$ having the maximum degree of fibrosis (F4) at non-invasive determinations. The proportion of advanced fibrosis (F4) cases was observed at the age category 41-62 with an equal distribution regardless of the patients gender. The patients with severe thrombocytopenia $(97,43 \%)$ had a maximum degree of fibrosis at non-invasive determinations, and almost $97 \%$ of the patients with endoscopic changes had F3 or F4 on Fibromax/Fibroscan.

Discussions. The limits of this study were the impossibility of follow-up in dynamics of the correlation between the degree of hepatic fibrosis estimated by Fibromax/Fibroscan and the parameters taken into account (being a retrospective study), the lack of witness lot, relatively small dimensions of the lot and the uneven distribution of the cases with clear dominance of advanced fibrosis.

Conclusions. Some biological and imagistic parameters correlate significantly with the result of the non-invasive estimates of the fibrosis degree. Of them, thrombocytopenia is a statistically significant marker, and the endoscopic criteria suggestive for portal hypertension suggest an advanced degree of hepatic fibrosis. The combined use of this factors within a score-system could increase the accuracy of the estimated fibrosis before the specific tests are done.
\end{abstract}

Keywords: chronic viral hepatitis, hepatic fibrosis, Fibroscan, Fibroma, upper digestive endoscopy, thrombocytopenia

Complicațiile clinice ale infecțiilor hepatice virale devin semnificative odată cu progresia leziunilor histologice - instalarea progresivă a fibrozei şi remanierea ineficientă a parenchimului hepatic, în asociere cu pierderea funcției şi posibilitatea transformării maligne. Astfel, cuantificarea corectă a modificărilor histologice pe parcursul evoluției bolii, în special a gradului de fibroză, permite formularea unui prognostic corect, alegerea momentului optim de iniţiere a terapiei antivirale şi a strategiei de screening pentru cancer hepatic la bolnavii cu hepatopatii cronice virale. Puncția biopsie hepatică este considerată gold-standard-ul stadializării fibrozei, însă metodele non-invazive au câştigat din ce în ce mai mult teren datorită creşterii accesibilităţii şi morbidităţii asociate scăzute (1).

O metaanaliză a arătat că Fibroscan-ul este foarte bun în a diferenția ciroza de absența acesteia, dar are o acuratețe scăzută în estimarea precisă a gradelor mai mici de fibroză (2). Fibromax-ul a dovedit că are o valoare predictivă pozitivă şi negativă înaltă pentru diagnosticarea gradelor avansate de fibroză la pacienții cu hepatită cronică C (3). Cu toate acestea, nu există până în prezent suficiente date care să permită o apreciere corectă şi perfect reproductibilă a gradului de fibroză sugerat de aceste metode. Capacitatea de a discrimina între stadiile timpurii şi avansate de fibroză hepatică este o problemă în dezbatere.

Stabilirea legăturii dintre diverşi parametri - clinici (vârsta, sex), virali (tipul virusului incriminat), biologici (numărul de trombocite), endoscopici (prezența semnelor de hipertensiune portală) - şi gradul de fibroză estimat prin Fibromax/Fibroscan ar permite evaluarea rapidă a gradului de fibroză chiar şi în centrele în care aceste testări sunt indisponibile şi stabilirea unor corelații fiziopatologice care ar contribui mai departe la aprofundarea mecanismelor de fibrogeneză şi a complicaţiilor evidențiabile ale acestui proces.

\section{MATERIAL ŞI METODĂ}

Într-un studiu retrospectiv, randomizat, efectuat pe parcursul unui an (ianuarie 2015 - februarie 2016) pe un lot de 132 pacienți cu hepatopatii virale în diferite stadii de evoluţie (hepatită cronică/ciroză hepatică), cu internări efectuate în cadrul Institutului de Boli Infecțioase „Prof. Dr. Matei Balş“ s-a urmărit corelarea parametrilor clinici, biologici şi endoscopici cu gradul fibrozei estimat prin metode non-invazive (Fibromax şi Fibroscan).

Criteriile de includere au fost vârsta peste 18 ani, etiologia virală a afectării hepatice (VHB, VHB+VHD, VHC), iar criteriile de excludere au fost prezența ascitei, sarcina în evoluție, obezitatea, coinfecția HIV, prezența dispozitivelor de stimulare cardiacă şi antecedentele de cancer hepatic, cancer hepatic în evoluție sau transplant hepatic. Pe baza acestor criterii, din lotul iniţial de 171 de pacienți, au fost selectați în final 132 de pacienți. Parametrii luați în considerare la constituirea bazei de date au fost: tipul virusului implicat, vârsta, sexul, numărul de trombocite, gradul de fibroză estimat prin Fibromax/Fibroscan şi criteriile endoscopice de hipertensiune portală. Factorii etiologici (tipul virusului implicat) şi cei care țin de pacient (vârstă, sex) reprezintă factori de risc pentru progresia fibrozei şi vor fi analizaţi ca atare. Trombocitopenia şi modificările endoscopice de hipertensiune portală sunt, practic, consecințe ale fibrozei, fibroza reprezentând un factor de risc pentru acestea şi în acest mod vor fi analizaţi mai departe (4). Menționăm ca sensurile sunt bidirecționale (Fig. 1), prin 


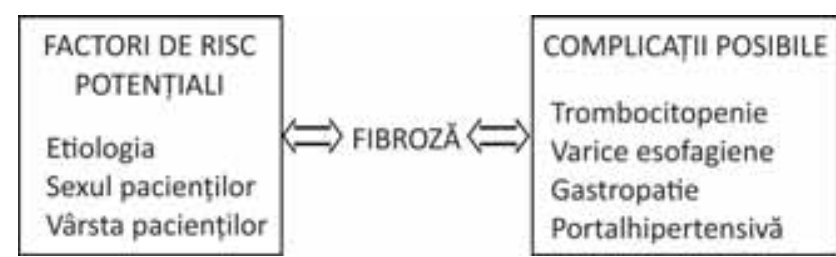

FIGURA 1. Interrelatia factori de risc-fibroză hepatică-complicații

urmare corelațiile sunt valabile în ambele sensuri în ceea ce priveşte interpretarea (5).

Pentru prelucrarea statistică a datelor am utilizat programele Microsoft Excel 2010 şi programul complementar de analiza statistică XLSTAT. În cadrul statisticii descriptive, am utilizat indicatori de tendință centrală (media aritmetică, modul, mediana) şi indicatori ce caracterizează împrăştierea datelor în jurul unei valori medii (intervalul, deviația standard, eroarea standard, percentilele şi coeficientul de variație). Pentru analiza corelației dintre modificările parametrilor clinici, biologici, endoscopici şi gradul fibrozei hepatice, am folosit tabele de contingență.

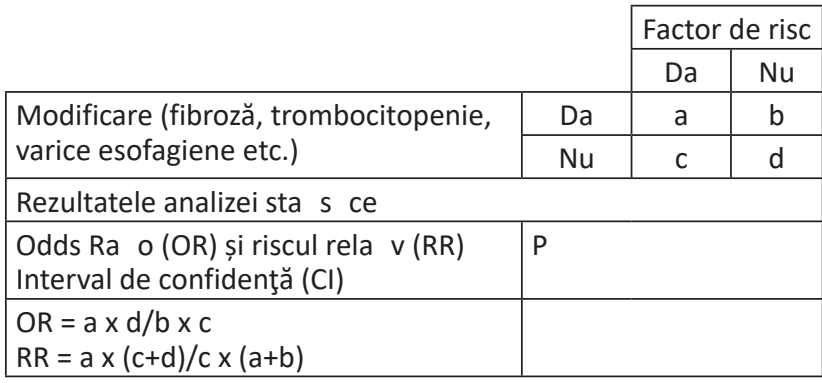

Am pornit de la premiza că prezența anumitor factori (un anume tip de virus/sexul masculin sau feminin/o anumită categorie de vârstă) predispune la un grad mai mare de fibroză şi că un grad mai avansat de afectare hepatică reprezintă un factor de risc pentru apariția unor modificări biologice (trombocitopenia) sau a hipertensiunii portale, evidențiată endoscopic $(4,5)$.

\section{REZULTATE}

Repartiţia pacienților în funcție de sex în lotul analizat arată o uşoară predominanţă a sexului feminin $(56,82 \%)$, relevând o distribuție egală a cazurilor sever afectate, indiferent de sexul pacienților, iar rezultatele prezintă semnificație statistică $(\mathrm{p}=0,018)$.

\begin{tabular}{|c|c|c|c|c|}
\hline \multirow{2}{*}{$\begin{array}{c}\text { Grad fibroză la } \\
\text { Fibroscan/Fibromax }\end{array}$} & \multirow{2}{*}{$\begin{array}{c}\text { Sex } \\
\text { masculin }\end{array}$} & $\begin{array}{c}\text { Sex } \\
\text { feminin }\end{array}$ & \multicolumn{2}{|c|}{$\begin{array}{c}\text { Proporția } \\
\text { pacienților }\end{array}$} \\
\cline { 4 - 5 } & & & $\mathrm{B}$ & $\mathrm{F}$ \\
\hline 0 & 0 & 3 & 0 & $4 \%$ \\
\hline 1 & 0 & 2 & 0 & $2,6 \%$ \\
\hline
\end{tabular}

\begin{tabular}{|c|c|c|c|c|}
\hline \multirow{2}{*}{$\begin{array}{l}\text { Grad fibroză la } \\
\text { Fibroscan/Fibromax }\end{array}$} & \multirow{2}{*}{$\begin{array}{c}\text { Sex } \\
\text { masculin }\end{array}$} & \multirow{2}{*}{$\begin{array}{c}\text { Sex } \\
\text { feminin }\end{array}$} & \multicolumn{2}{|c|}{$\begin{array}{l}\text { Proporția } \\
\text { pacienților }\end{array}$} \\
\hline & & & B & $\mathrm{F}$ \\
\hline 2 & 8 & 1 & $14 \%$ & $1,3 \%$ \\
\hline 3 & 16 & 25 & $28 \%$ & $33 \%$ \\
\hline 4 & 33 & 45 & $57 \%$ & $60 \%$ \\
\hline Total & 57 & 75 & & \\
\hline$p$ & \multicolumn{4}{|c|}{0,018} \\
\hline
\end{tabular}

În ceea ce priveşte vârsta pacienților incluşi, aceasta variază între 18 şi 84 de ani. S-a observat un risc relativ de 1,34 de a avea o afectare hepatică mai severă $(F 3$, F4) la categoria de vârstă 41-62 de ani comparativ cu grupele de vârstă 18-40 de ani şi 63-84 de ani, dar rezultatul nu prezintă semnificație statistică $(p=0,293)$.

În ceea ce priveşte etiologia virală, în cadrul lotului analizat există doar cazuri de infecție VHC, VHB, VHB + VHD, dar nu şi cazuri de infecție VHB + VHC. Există un procent foarte scăzut al cazurilor cu afectare hepatică incipientă $(2,27 \%$ - F0 şi 1,51\% - F1). Predominanța clară a cazurilor cu grad avansat de fibroză face dificilă sau chiar imposibilă evaluarea semnificației statistice în unele aspecte (Fig. 2).

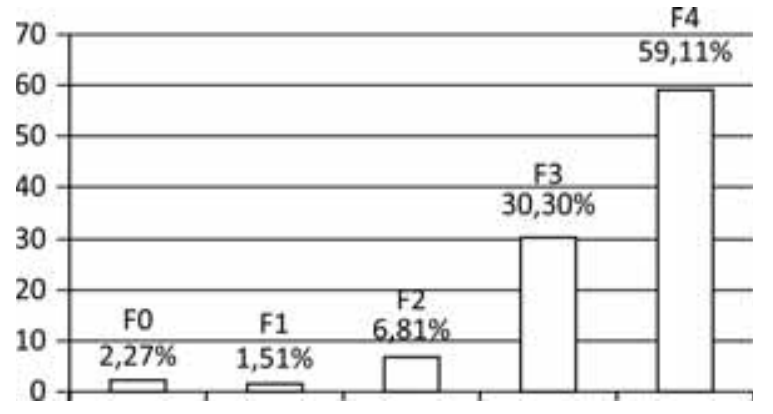

FIGURA 2. Distribuția procentuală a gradului de fibroză hepatică

Din punct de vedere al etiologiei, în lotul nostru de 132 de pacienţi cu hepatopatii (hepatită cronică sau ciroză hepatică) predomină net cazurile de infecție cu VHC (75,76\%).

\begin{tabular}{|c|c|c|c|}
\hline $\begin{array}{c}\text { Gradul de fibroză hepatică } \\
\text { la Fibromax/Fibroscan }\end{array}$ & $\begin{array}{c}\text { Etiologie } \\
\text { VHB }\end{array}$ & $\begin{array}{c}\text { Etiologie } \\
\text { VHC }\end{array}$ & $\begin{array}{c}\text { Etiologie } \\
\text { VHB+VHD }\end{array}$ \\
\hline F0 & 1 & 2 & 0 \\
\hline F1 & 0 & 2 & 0 \\
\hline F2 & 2 & 7 & 0 \\
\hline F3 & 9 & 31 & 0 \\
\hline F4 & 5 & 58 & 15 \\
\hline Total & 17 & 100 & 15 \\
\cline { 2 - 4 } & \multicolumn{3}{|l}{} \\
\hline
\end{tabular}

Ca o particularitate a lotului analizat s-a observat că toți pacienții cu infecție concomitentă 
VHB+VHD au prezentat grad maxim de fibroză (F4) la determinările non-invazive. Semnificația statistică a acestei observații nu a putut fi analizată din cauza absenței unui număr de cazuri cu grad mai mic de fibroză, care să constituie un lot martor. De asemenea, reținem - ca rezultate cu semnificație statistică - probabilitatea de $31 \%$ ca un pacient cu infecție VHC să aibă un grad de fibroză F3 şi 7\% pentru F2 şi o probabilitate de $11,76 \%$ ca un pacient cu infecție VHB să aibă un stadiu de fibroză F2 la determinări non-invazive.

\begin{tabular}{|c|c|c|c|c|}
\cline { 2 - 5 } \multicolumn{1}{c|}{} & \multicolumn{2}{c|}{ Infecție VHB } & \multicolumn{2}{c|}{ Infecție VHC } \\
\hline $\begin{array}{c}\text { Stadiu de } \\
\text { fibroză }\end{array}$ & Probabilitate & $\mathrm{p}$ & Probabilitate & $\mathrm{p}$ \\
\hline F2 & $11,76 \%$ & 0,00078 & $7 \%$ & 0,00000 \\
\hline F3 & $52,94 \%$ & 0,75086 & $31 \%$ & 0,00000 \\
\hline F4 & $29,41 \%$ & 0,99999 & $58 \%$ & 1 \\
\hline
\end{tabular}

A fost urmărită şi corelaţia dintre valoarea trombocitelor şi gradul de fibroză hepatică, cunoscut fiind faptul că variabilele clinice cum ar fi vârsta, sexul şi severitatea afectării hepatice influențează amploarea trombocitopeniei (2). S-a observat că majoritatea pacienților cu trombocitopenie severă $(<99.999 / \mu 1)$, respectiv $97,43 \%$ au grad maxim de fibroză (F4) la determinările non-invazive, comparativ cu $55,55 \%$ dintre cei cu trombocitopenie uşoară (100.000-149.999/ $\mu 1)$ şi doar 37,87\% dintre cei cu număr normal de trombocite $(>150.000 / \mu 1)$. Rezultatele arată o corelație strânsă între prezența trombocitopeniei moderate sau severe şi gradul de fibroză F4 determinat non-invaziv, iar corelația este semnificativă din punct de vedere statistic.

\begin{tabular}{|l|c|c|c|}
\cline { 3 - 4 } \multicolumn{2}{c|}{} & \multicolumn{2}{c|}{ Fibroză F4 } \\
\cline { 2 - 4 } \multicolumn{1}{c|}{} & DA & NU \\
\cline { 2 - 4 } \multicolumn{1}{c|}{} & DA & 38 & 40 \\
\hline NU & 1 & 53 \\
\hline $\begin{array}{l}\text { Rezultatele analizei sta s ce } \\
\text { Odds Ra o (OR) și riscul rela v (RR) } \\
\text { Interval de confidenţă (CI 95\%) }\end{array}$ & \multicolumn{2}{|c}{ P } \\
\hline $\begin{array}{l}\text { OR }=50,35 \\
\text { RR }=26,30\end{array}$ & 0,000000006159161 \\
\hline
\end{tabular}

Altfel spus, prezența unui număr de trombocite sub valoarea menționată se corelează cu o probabilitate foarte mare de a obține stadiul F4 la determinările non-invazive, iar riscul relativ al pacienților cu fibroză F4 de a avea trombocitopenie severă este de 26,3 .

În ceea ce priveşte criteriile endoscopice de hipertensiune portală, două modificări au fost luate în considerare la constituirea bazei de date, şi anume: absența/prezența varicelor esofagiene, gradul acestora (mici, moderate, mari) şi absența/prezența gastropatiei portal-hipertensive (5). Nu au fost întâlnite cazuri de varice esogastrice sau gastrice şi nici afectare duodenală în cadrul sindromului de hipertensiune portală. Dintre cei 132 de pacienți, în 35 de cazuri nu au fost constatate modificări endoscopice compatibile cu hipertensiunea portală. La aceşti pacienți s-a observat că două treimi $(68,57 \%)$ prezentau un grad mic de fibroză (F0, F1 sau F2) la determinările non-invazive. În contrast, aproape 97\% dintre pacienții cu modificări endoscopice portal-hipertensive au avut rezultate F3 sau F4 la Fibroscan/Fibromax. Analiza statistică a datelor de mai sus relevă faptul că pacienții cu modificări endoscopice compatibile cu existența hipertensiunii portale prezintă un risc relativ de 3,71 de a avea un grad mai mare de fibroză (F3 sau F4) la determinările non-invazive, iar constatarea are semnificație statistică $(p<0,05)$.

\begin{tabular}{|l|c|c|c|}
\cline { 3 - 4 } \multicolumn{1}{c|}{} & \multicolumn{3}{c|}{ Criterii EDS de HTP } \\
\cline { 3 - 4 } \multicolumn{2}{c|}{} & DA & NU \\
\hline \multirow{2}{*}{ Fibroză importantă (F3 sau F4) } & DA & 94 & 24 \\
\cline { 2 - 4 } & NU & 3 & 11 \\
\hline Rezultatele analizei sta s ce & \multicolumn{2}{|c}{$\mathrm{P}$} \\
\hline $\begin{array}{l}\text { Odds Ra o (OR) și riscul rela v (RR) } \\
\text { Interval de confidenţă (CI 95\%) }\end{array}$ & 0,0000030462 \\
\hline $\begin{array}{l}\text { OR }=14,36 \\
\text { RR }=3,71\end{array}$ & \\
\hline
\end{tabular}

Frecvența gastropatiei portal-hipertensive la nivelul lotului a fost de asemenea mare, 92 de pacienți $(69,7 \%)$ prezentând aspect endoscopic tipic. S-a constatat o creştere liniară a proporției de pacienți cu modificări endoscopice caracteristice pentru gastropatia portal-hipertensivă odată cu creşterea gradului de fibroză hepatică, de la $0 \%$ la pacienții cu F1 până la aproape $90 \%$ la pacienții cu stadii avansate (F4). Prezența unui grad mare de fibroză hepatică $(\mathrm{F} 4)$ s-a asociat cu un risc relativ de 3,33 de a prezenta aspect endoscopic de gastropatie portalhipertensivă, iar corelaţia este semnificativă din punct de vedere statistic. De asemenea, prezența unui grad de fibroză F3 sau F4 la Fibroscan/Fibromax se asociază cu un risc relativ de 1,33 pentru dezvoltarea gastropatiei portal-hipertensive, iar rezultatul are semnificație statistică.

În ceea ce priveşte frecvența varicelor esofagiene la nivelul lotului studiat, 76 din totalul de 132 de pacienți analizați $(57,58 \%)$ prezentau această complicaţie la momentul intrării în lot. Cei mai mulți $(67,1 \%)$ aveau varice esofagiene mici, $23,68 \%$ varice medii şi doar $9,22 \%$ dintre pacienţi prezentau 
varice esofagiene de dimensiuni mari. Prezența unui grad mare de fibroză $(F 3, F 4)$ la determinările non-invazive s-a asociat cu un risc relativ de 1,24 de a prezenta varice esofagiene de orice dimensiune la examinarea endoscopică, iar relația are semnificație statistică.

\begin{tabular}{|c|c|c|c|}
\hline & \multicolumn{2}{|c|}{ Fibroză F3, F4 } \\
\hline & & DA & NU \\
\hline \multirow[t]{2}{*}{ Prezenţa de VE la EDS } & $\mathrm{DA}$ & 74 & 2 \\
\hline & $\mathrm{NU}$ & 44 & 12 \\
\hline \multicolumn{4}{|c|}{ Rezultatele analizei sta s ce } \\
\hline \multicolumn{2}{|c|}{$\begin{array}{l}\text { Odds Ra o (OR) și riscul rela v (RR) } \\
\text { Interval de confidenţă (Cl 95\%) }\end{array}$} & \multicolumn{2}{|c|}{$P$} \\
\hline \multicolumn{2}{|l|}{$\begin{array}{l}\mathrm{OR}=10,09 \\
\mathrm{RR}=1,24\end{array}$} & \multicolumn{2}{|c|}{0,00052} \\
\hline
\end{tabular}

De asemenea, prezența unui grad maxim de fibroză (F4) estimat non-invaziv s-a asociat cu un risc relativ de 1,2 al pacienților de a prezenta varice esofagiene medii sau mari la examinarea endoscopică, iar constatarea are semnificație statistică.

\section{DISCUŢII}

Pe baza datelor obținute în cadrul acestui studiu, s-au desprins mai multe aspecte. Etiologic, a predominat $(75,76 \%)$ infecția cu VHC. Gradul mediu de fibroză al lotului respectiv a fost cel mai mare în cazul coinfecției VHB + VHD şi cel mai mic in cazul infecției cu VHB. Sexul feminin este mai predispus să dezvolte o fibroză extensivă față de sexul masculin, dar această constatare nu are semnificație statistică. Vârsta mai avansată nu reprezintă un factor de risc pentru o boală mai severă, majoritatea cazurilor cu stadiu F3 sau F4 situându-se în grupa de vârstă mijlocie (41-62 de ani).

S-a observat însă o corelaţie strânsă între prezența trombocitopeniei moderate sau severe $(<99.999 / \mu 1)$ şi gradul de fibroză F4 determinat non-invaziv, iar corelația a fost semnificativă din punct de vedere statistic. S-a observat, de asemenea, că prezența unui grad mare de fibroză (F3 sau F4) la determinările non-invazive s-a asociat cu prezența varicelor esofagiene $\mathrm{sau} /$ şi a gastropatiei portal-hipertensive la examinarea endoscopică, iar corelația a avut semnificație statistică.

\section{CONCLUZII}

Astfel, putem concluziona că anumiți parametri biologici şi endoscopici se corelează semnificativ cu rezultatul estimărilor non-invazive ale gradului de fibroză hepatică. Dintre aceştia, trombocitopenia este un marker cu mare semnificație, inclusiv din punct de vedere statistic, prezența acestuia sugerând o mare probabilitate ca pacientul să se afle într-un stadiu avansat de fibroză hepatică. Totodată, criteriile endoscopice sugestive pentru hipertensiunea portală (atât gastropatia portalhipertensivă, cât şi varicele esofagiene sau asocierea dintre ele) sugerează un grad avansat de fibroză hepatică, dimensiunile medii şi mari ale varicelor corelându-se pozitiv cu un stadiu maxim de fibroză estimată non-invaziv.

Studiile din ultimii ani acreditează ideea că o rigiditate hepatică $>25 \mathrm{kPa}$ apreciată prin elastografie tranzitorie (Fibroscan) are o acuratețe de peste $90 \%$ în diagnosticare hipertensiunii portale clinic semnificative $(6,7)$.

Utilizarea combinată a acestor factori (studiați în lotul nostru) în cadrul unor sistemescor ar putea creşte acuratețea fibrozei prognosticate anterior efectuării testelor specifice. De asemenea, luarea în calcul a unor factori adiționali biologici sau imagistici, cum ar fi valoarea INR sau calibrul venei porte determinate ecografic, în asociere cu numărul de trombocite şi criteriile endoscopice de hipertensiune portală, combinate în cadrul unor scoruri adecvate, ar avea potențialul ca în viitor să completeze sau chiar să substituie (prin valoarea informativă) necesitatea explorărilor de tip Fibromax/Fibroscan, cel puțin în ceea ce priveşte abordarea clinică curentă (iniţierea şi monitorizarea terapiei antivirale).

Una dintre limitele acestui studiu a fost imposibilitatea urmăririi în dinamică a corelației dintre gradul de fibroză hepatică estimat la Fibromax/Fibroscan şi parametrii luați în calcul, întrucât studiu a fost retrospectiv. De asemenea, alte limite ar fi lipsa unui lot martor (de exemplu hepatopatii non-virale), dimensiunile relativ reduse ale lotului şi repartiţia neuniformă a cazurilor, cu dominanța clară a fibrozelor avansate. 


\section{BIBLIOGRAFIE}

1. Martinez S.M., Crespi G., Navassa M. et al. Noninvasive assessment of liver fibrosis. Hematology 2011; 53:325-35

2. Friedrich-Rust M., Martens S., Sarasin C. et al. Performance of transient electrography for the staging of liver fibrosis: A metaanalysis. Gastroenterology 2008; 134:960-74

3. Poynard T., McHutchinson J., Manns M. et al. Biochemical surrogate markers of liver fibrosis and activity in a randomized trial of peginterferon alpha-2b and ribavirin. Hepatology 2003; 38:481-92.

4. Olariu M., Olariu C., Olteanu D. Thrombocytopenia in chronic hepatitis C, J. Gastrointest. Liver Dis, 2010,1 9(4):381-385
5. Patrick S. Kamath, Vijay Hashish. Overview of cirrhosis. In: Sleisenger and Fordtran's Gastrointestinal and Liver disease $10^{\text {th }} \mathrm{ed}$. Saunders, an imprint of Elsevier Inc; 2016: 1254-1260.

6. Augustin S. et al. Detection of early portal hypertension with routine data And liver stiffness in patients with asymptomatic liver disease: a prospective study. J Hepatic 2014; 60: 561-569.

7. Robin M.A. et al. Liver stiffness accurately predicts portal hypertension related complication in patients with chronic liver disease: A prospective study. J Hepatol. 2011; 55: 1017-1024

Conflict of interest: none declared Financial support: none declared 